Article

\title{
Transpiration Responses of Herbicide-Resistant and -Susceptible Palmer Amaranth (Amaranthus palmeri (S.) Wats.) to Progressively Drying Soil
}

\author{
Koffi Badou-Jeremie Kouame ${ }^{1}$, Mary C. Savin ${ }^{1}\left(\mathbb{D}\right.$, Gulab Rangani $^{1}{ }^{(D}$, Thomas R. Butts $^{1}(\mathbb{D}$, \\ Matthew B. Bertucci ${ }^{2}$ (D) and Nilda Roma-Burgos $1, *(\mathbb{D}$
}

Citation: Kouame, K.B.-J.; Savin, M.C.; Rangani, G.; Butts, T.R.; Bertucci, M.B.; Roma-Burgos, N. Transpiration Responses of Herbicide-Resistant and -Susceptible Palmer Amaranth (Amaranthus palmeri (S.) Wats.) to Progressively Drying Soil. Agriculture 2022, 12, 335. https://doi.org/10.3390/

agriculture12030335

Academic Editor:

Bernhard Huchzermeyer

Received: 19 January 2022

Accepted: 21 February 2022

Published: 26 February 2022

Publisher's Note: MDPI stays neutral with regard to jurisdictional claims in published maps and institutional affiliations.

Copyright: (C) 2022 by the authors. Licensee MDPI, Basel, Switzerland. This article is an open access article distributed under the terms and conditions of the Creative Commons Attribution (CC BY) license (https:// creativecommons.org/licenses/by/ $4.0 /)$.
1 Department of Crop, Soil and Environmental Sciences, University of Arkansas, Fayetteville, AR 72704, USA; kbkouame@uark.edu (K.B.-J.K.); msavin@uark.edu (M.C.S.); grangani@uark.edu (G.R.); tbutts@uada.edu (T.R.B.)

2 Department of Horticulture, University of Arkansas, Fayetteville, AR 72701, USA; bertucci@uark.edu

* Correspondence: nburgos@uark.edu

\begin{abstract}
Drought events are predicted to increase in the future. Evaluating the response of herbicideresistant and -susceptible weed ecotypes to progressive drought can provide insights into whether resistance traits affect the fitness of resistant weed populations. Two experiments were conducted in the greenhouse between January and May 2021 to evaluate drought tolerance differences between Palmer amaranth accessions resistant to $S$-metolachlor or glyphosate and their susceptible counterparts. The accessions used were $S$-metolachlor-resistant (17TUN-A), a susceptible standard (09CRW-A), and glyphosate-resistant (22-165 EPSPS copies) and glyphosate-susceptible (3-10 EPSPS copies) plants from accession 16CRW-D. Daily transpiration of each plant was measured. The daily transpiration rate was converted to normalized transpiration ratio (NTR) using a doublenormalization procedure. The daily soil water content was expressed as a fraction of transpirable soil water (FTSW). The threshold FTSW (FTSWcr), after which NTR decreases linearly, was estimated using a two-segment linear regression analysis. The data showed differences between $S$-metolachlorresistant and -susceptible accessions $(p \leq 0.05)$. The FTSW remaining in the soil at the breakpoint for the $S$-metolachlor-susceptible accession (09CRW-A) was $0.17 \pm 0.007$. The FTSW remaining in the soil at the breakpoint for the $S$-metolachlor-resistant accession (17TUN-A) was $0.23 \pm 0.004$. The FTSW remaining in the soil at the breakpoint for the glyphosate-resistant and glyphosate-susceptible plants (16CRW-D) was $0.25 \pm 0.007$ and $0.25 \pm 0.008$, respectively. Although the mechanism endowing resistance to $S$-metolachlor might have contributed to increased drought tolerance, follow-up experiments are needed in order to verify this finding. Increased EPSPS copy numbers did not improve the drought tolerance of Palmer amaranth. As droughts are predicted to increase in frequency and severity, these results suggest that $S$-metolachlor-resistant and glyphosate-resistant Palmer amaranth populations will not be at a competitive disadvantage compared to susceptible genotypes. Alternative and diverse management strategies will be required for effective Palmer amaranth control, regardless of herbicide resistance status.
\end{abstract}

Keywords: drought tolerance; threshold FTSW; EPSPS gene amplification; S-metolachlor resistance; glyphosate resistance

\section{Introduction}

Drought can negatively affect physiological and biochemical processes, and causes yield reduction [1]. As the world's largest exporter of major grain and oilseed crops, the United States accounted for $49 \%$ and $46 \%$ of total global exports of corn (Zea mays L.) and soybeans (Glycine max (L.) Merr.), respectively, between 2008 and 2010 [2]. However, the 'flash drought' event in the US in 2012 disrupted the production of major crops and affected international grain markets [2]. This most detrimental drought of the past century in the 
US Midwest had a greater impact on agricultural systems (crops and grasslands) than on forests [3]. Drought frequency and severity are likely to increase in the future [3-5]; consequently, yields of crops such as corn and soybeans are predicted to decline by $8-21 \%$ [6]. Under rainfed conditions, seasonal water supply and soil water-holding capacity are major determinants of crop productivity [7]. The largest corn and soybean production area-the US Corn Belt-is 92\% rainfed; thus, it is vulnerable to drought occurrences [8]. Furthermore, under irrigated conditions, irrigation does not always fully supply crop water demand during droughts [9].

Evapotranspiration (ET) - the sum of water used by plants via transpiration and direct soil water loss via evaporation-informs us about soil moisture availability [10]. Plant transpiration is a key component of soil water consumption; it is a crucial physiological process that is strongly related to biomass production [11]. Under drought, plants can sense water stress around the roots, and respond by sending chemical signals such as increased abscisic acid (ABA) production to close the stomates [12]. The determination of the threshold value for the initiation of stomatal closure is critical for understanding plants' physiological responses to drought [13]. A major challenge in studying plants' responses to soil drying is the ability to characterize soil water content in a way that is relevant to biological processes [14]. The simple method of volumetric measurement of soil water content was reported to be a good predictor of physiological responses in plants [15-19].

One useful parameter to monitor soil drying and corresponding plant response to progressive drought stress is the fraction of transpirable soil water (FTSW) - this is the amount of water available to plants at any given time in the drying cycle relative to the total amount of water available for transpiration at the pot-holding capacity. Plant transpiration in response to drying soil has been well characterized by previous research, and is reported to display two phases: (1) the initial plateau, where transpiration is optimal, and (2) a linear decline in response to a drying soil. These phases are connected by a breakpoint-also known as a threshold value-for the initiation of stomatal closure [15-18]. The threshold value (FTSWcr) is a crucial parameter for comparing populations, ecotypes, or genotypes. Differences in threshold values at which transpiration begins to decline can provide valuable information about plant water use patterns and stomatal closure during a drying cycle [16-18].

Palmer amaranth (Amaranthus palmeri (S.) Wats.) has the ability to adapt to various stress conditions [20]; it uses osmoregulation to keep stomates open during drought in order to continue carbon fixation [21]. This trait may be modified by biochemical, physiological, or structural modifications in the plant that are associated with resistance to herbicides. The evolution of resistance to herbicides in Palmer amaranth and many other weedy species is a survival mechanism brought forth by the persistent, strong selection pressure from recurrent herbicide use. These coping mechanisms may have positive or negative effects on the fitness of resistant weedy plants, which could affect weed fecundity or competitive ability. Previous research has documented the association of herbicide resistance traits with fitness costs and competitive disadvantages in the absence of herbicide selection pressure that favors resistant plants [22,23]. Additionally, gene families (cytochrome P450s and GSTs) involved in non-target-site resistance (NTSR) to herbicides play a role in plant protection against, and survival in, adverse environmental conditions [24]. In Arkansas, Palmer amaranth has evolved target-site resistance to glyphosate due to EPSPS (5-enolpyruvylshikimate-3-phosphate synthase) gene amplification [25] and NTSR to S-metolachlor via upregulation of GSTs [26]. Harboring these mechanisms may impart some latent benefits, such as increased tolerance to abiotic stress-especially with resistance to $S$-metolachlor-due to the involvement of GSTs. One indicator of this is adjustment in transpiration rates under drought stress. The objective of this research was to quantify the transpiration changes that occur in herbicide-resistant and -susceptible Palmer amaranth accessions subjected to a progressive drying cycle. 


\section{Materials and Methods}

Two experiments were conducted in the greenhouse from January to May 2021 at the Shult Agricultural Research \& Extension Center, University of Arkansas, Fayetteville, and were repeated in time. The experiments involved accessions resistant and susceptible to $S$-metolachlor, as well as accessions resistant and susceptible to glyphosate. Resistance to $S$-metolachlor was due to GST overexpression [26], while resistance to glyphosate was due to EPSPS amplification [25].

2.1. Comparison of Transpiration Rates between Glyphosate-Resistant and-Susceptible Plants That Differ in EPSPS Copy Number

Plant Material Preparation

Glyphosate-resistant Palmer amaranth accession 16CRW-D was collected from Crawford County (Arkansas) in 2016. A total of 100 seeds were planted in two 50-cell trays filled with Sunshine ${ }^{\circledR}$ Premix \#1 (Sun Gro Horticulture, Bellevue, WA, USA). All healthy seedlings $(8 \mathrm{~cm}$ tall) were transplanted to $13 \mathrm{~cm} \times 11 \mathrm{~cm}$ (diameter-by-depth) pots filled with the same soil. Plants were fertilized weekly using a water-soluble, all-purpose plant food (Scotts Miracle-Gro Products, Marysville, OH, USA) containing 24\% N, 8\% P, and $16 \% \mathrm{~K}$.

Leaf tissue was collected from each plant to determine the relative EPSPS gene copy number using the method described in [25]. Briefly, genomic DNA was extracted from approximately $100 \mathrm{mg}$ of leaf tissue using a modified CTAB protocol, and then quantified using a NanoDrop spectrophotometer (Thermo Scientific, Wilmington, DE, USA). The EPSPS copy number was determined by quantitative real-time polymerase chain reaction (qPCR) relative to the $A 36$ gene [25]. The primers were A36_F244 (5'TTGGAACTGTC AGAGCAACC3') and A36_R363 (5'GAACCCACTT CCA CCAAAAC3') for the reference gene, and EPSPS1CNF (5'ATGTTGGACGCT CTCAGAACTCTTGGT3') and EPSPS1CNR (5'TGAATTTCCTCCAGCAACGGCAA3') for EPSPS. Two technical replicates of each genomic DNA template $(20 \mathrm{ng})$ were amplified in a $10 \mu \mathrm{L}$ reaction volume using SYBR Green Master Mix (Bio-Rad, Hercules, CA). For qPCR, the $10 \mu \mathrm{L}$ reactions were prepared using a Master Mix composed of $5 \mu \mathrm{L}$ of SYBR iTaq (Bio-Rad, Hercules, CA, USA), $0.5 \mu \mathrm{L}$ of $5 \mu \mathrm{M}$ forward primer, $0.5 \mu \mathrm{L}$ of $5 \mu \mathrm{M}$ reverse primer, $3 \mu \mathrm{L}$ of water, and $1 \mu \mathrm{L}$ of gDNA. The thermoprofile was $95^{\circ} \mathrm{C}$ for $15 \mathrm{~min}$, then 30 cycles of $95{ }^{\circ} \mathrm{C}$ for $30 \mathrm{~s}$ and $60{ }^{\circ} \mathrm{C}$ for $1 \mathrm{~min}$. Melt curve analysis was conducted by holding the samples at $95^{\circ} \mathrm{C}$ for $5 \mathrm{~min}$, then reducing the temperature to $55^{\circ} \mathrm{C}$ for $5 \mathrm{~min}$, followed by increasing the temperature by $0.5^{\circ} \mathrm{C}$ every $10 \mathrm{~s}$ up to $95^{\circ} \mathrm{C}$.

Twenty-four plants of similar size ( $25 \mathrm{~cm}$ tall; 12 with increased EPSPS copy) were transplanted into pots, $19 \mathrm{~cm}$ in diameter $x 17 \mathrm{~cm}$ deep, at the same depth of $11 \mathrm{~cm}$. Each pot contained $2.5 \mathrm{~kg}$ of a 1:1 mixture of field soil and Sunshine ${ }^{\circledR}$ Premix \#1 (Sun Gro Horticulture, Bellevue, WA, USA). The field soil, a Roxana silt loam (USDA-SCS, 1979), had $\mathrm{pH} 7.3,112 \mu \mathrm{mhos} / \mathrm{cm}$ EC, $0.04 \%$ total N, and 0.4\% total C, and was collected from the Vegetable Research Station of the University of Arkansas, Kibler, Arkansas, USA.

\subsection{Differences in Drought Tolerance between S-Metolachlor-Susceptible and-Resistant Accessions Plant Material Preparation}

The resistant and susceptible accessions referred to as 17TUN-A and 09CRW-A, respectively, were used for the experiment. Accession 17TUN-A showed resistance to $S$-metolachlor, and resistant plants required up to 5 times more $S$-metolachlor to reduce seedling emergence by 50\% (Kouame et al., unpublished). Seeds of accessions 09CRW-A and 17TUN-A were collected in Arkansas in 2009 and Mississippi in 2017, respectively. One hundred seeds of each accession were grown in 50-cell trays filled with commercial soil, as described in Experiment 1 . Seedlings $(8 \mathrm{~cm}$ tall) were transplanted and maintained as described previously. Later, plants of similar size $(25 \mathrm{~cm}$ tall) were transplanted into larger pots, $19 \mathrm{~cm}$ in diameter $\times 17 \mathrm{~cm}$ deep, filled with $2.5 \mathrm{~kg}$ of a 1:1 mixture of field soil and Sunshine ${ }^{\circledR}$ Premix \#1. 


\subsection{Dry-Down Treatment}

The experiment was conducted as a completely randomized design with six replicates (Figure 1). The experimental units were pots containing one plant per pot. The pots were re-randomized every other day during the experiment.

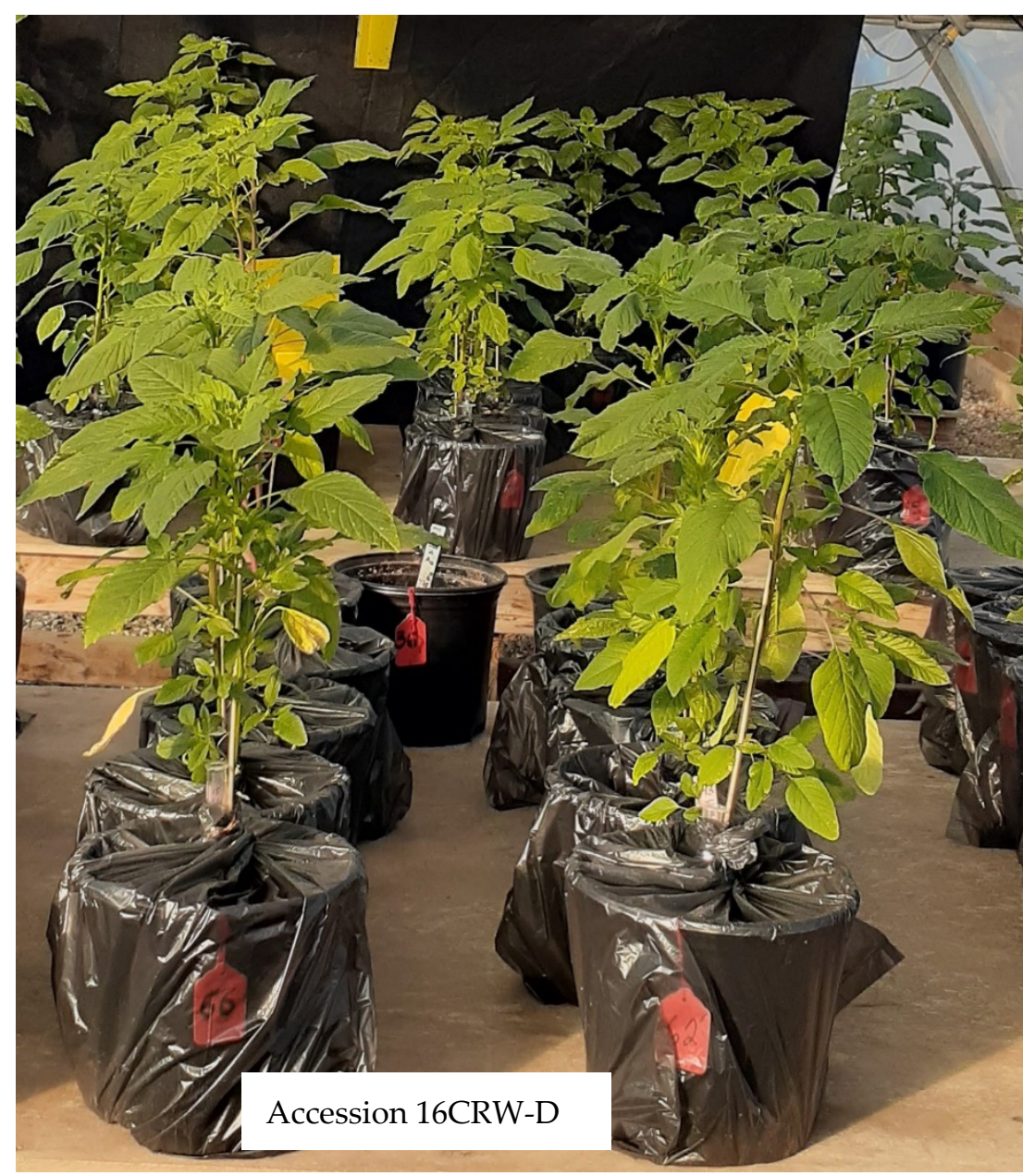

Figure 1. Setup of a greenhouse experiment to evaluate the transpiration responses of herbicideresistant and -susceptible Palmer amaranth (Amaranthus palmeri (S.) Wats.) to progressively drying soil, at the Shult Agricultural Research \& Extension Center, University of Arkansas, Fayetteville, AR, USA, in 2021.

The drought factor had two levels (well-watered and water-deficit). The method used was adapted from previous research [27]. The plants were watered daily and fertilized weekly with a water-soluble, all-purpose plant food (Scotts Miracle-Gro Products, Marysville, OH, USA) containing 24\%, 8\%, 16\%, 0.02\%, 0.07\%, 0.15\%, 0.05\%, 0.0005\%, and $0.06 \% \mathrm{~N}, \mathrm{P}_{2} \mathrm{O}_{5}, \mathrm{~K}_{2} \mathrm{O}, \mathrm{B}, \mathrm{Cu}, \mathrm{Fe}, \mathrm{Mn}, \mathrm{Mo}$, and $\mathrm{Zn}$, respectively, until dry-down initiation. The evening before starting the dry-down, pots were saturated and allowed to drain overnight. The pots were enclosed in black plastic bags [17,28], and each bag opening was sealed around the plant stem with twist ties to prevent evaporation. A $6 \mathrm{~mL}$ syringe barrel was inserted between the base of the plant and the plastic bag for water replenishment. Newly bagged pots were weighed to determine their gravimetric water content at water holding capacity. The pots were weighed daily at 4 p.m., in the same order, for the duration of the experiment. Daily transpiration was calculated as the difference in mass of each pot on successive days. To maintain well-watered conditions but prevent anaerobic conditions in the control pots [19], the plants were maintained at $80 \%$ of well-watered pot capacity weight. For the water stress treatments, the six plants (or replicates) of each accession were watered 
to a target level of $50 \mathrm{~mL}$ below the amount of water lost via transpiration in the past $24 \mathrm{~h}$, starting at the initiation of drought stress treatment. Five pots with water-saturated soil in the greenhouse, without plants, were used to estimate the daily evaporation rate.

\subsubsection{Daily Transpiration and Normalized Transpiration Ratio}

The transpiration data were analyzed using a double-normalization procedure $[15,19]$. A first normalization minimized the influence of daily fluctuations in transpiration on the transpiration rate (TR) of stressed plants over time [15,17], by normalizing daily transpiration rates for the stressed plants divided by the average for non-stressed plants for the same day [19], using Equation (1):

TR of stressed plant $=($ Transpiration of stressed plant $) /($ Average transpiration of control plant $)$

The second normalization-normalized transpiration ratio (NTR)-allowed the normalized transpiration rate of each plant to be centered on a value of 1 . A mean TR was calculated for each plant for the first $3 \mathrm{~d}$ of the experiment, when the soil water content in each pot was high $[15,17]$. The daily TR for each stressed plant was divided by the mean TR of the same plant during the well-watered stage, giving a daily normalized transpiration ratio (NTR) [17-19], as shown in Equation (2).

$$
\text { NTR }=(\text { Daily TR }) /(\text { Average TR of the first } 3 \mathrm{~d})
$$

The treatments were maintained for each resistant or susceptible accession or plant until the NTR value dropped below 0.1, defined as the endpoint of the drying cycle $[15,19]$.

\subsubsection{Drought Stress Level in the Root Zone}

The FTSW was defined as the amount of gravimetric water available for plant transpiration at any given time during the drying cycle relative to the total amount of water available for transpiration at the pot's water-holding capacity. Determination of the FTSW was accomplished using Equation (3):

daily FTSW = (Daily pot weight - Final pot weight $) /($ Initial pot weight - Final pot weight $)$

Calculations of FTSW were carried out using the daily average of the beginning and ending interval pot weights $[27,29]$.

\subsection{Data Analysis}

The relationship between NTR and FTSW was quantified using a two-segment linear regression analysis [17]. The NTR calculated for each pot on each day was plotted for each accession versus the corresponding FTSW. The two-segment linear regression analysis was accomplished for the six drying pots studied for the $S$-metolachlor-resistant and -susceptible accessions, and for the glyphosate-resistant and -susceptible plants, using nonlinear least squares regression (NLS) on R version 4.0.0 [30]. The intersection of the two linear regressions is the FTSW at the breakpoint in the soil drying cycle. The resulting $\mathrm{R}^{2}$ for the regression analysis and breakpoint values for the NTR for each accession were determined, and differences between breakpoints were compared using confidence intervals $(\alpha=0.05)[31,32]$.

\section{Results}

3.1. Differential Response of S-Metolachlor-Resistant and-Suceptible Accessions to Progressive Drying

The two-segmented linear regression analysis [33] was used to relate NTR to FTSW for plants subjected to progressive drying treatment (Figure 2). 

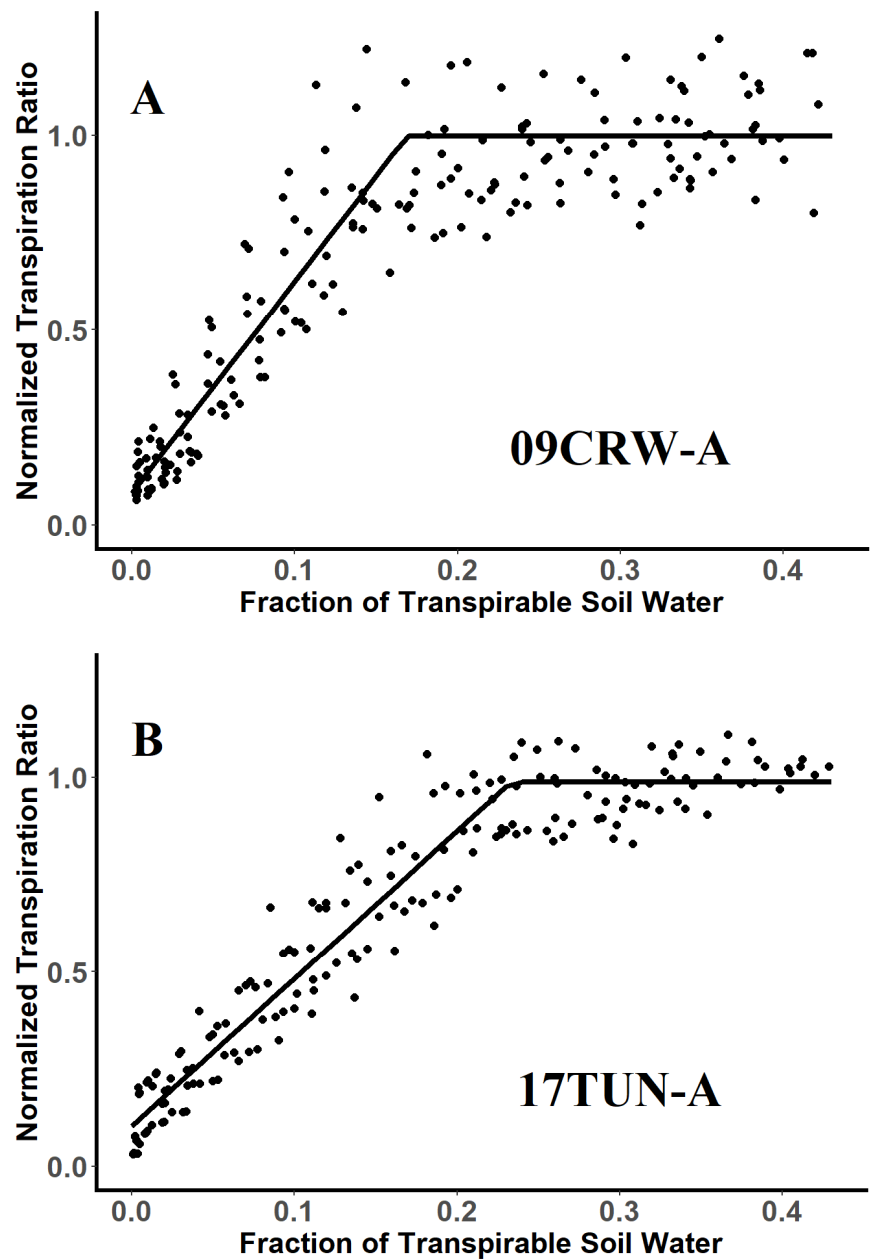

Figure 2. Relationship between normalized transpiration ratio (NTR) and fraction of transpirable soil water (FTSW) during the soil drying cycle for S-metolachlor-susceptible (09CRW-A) (panel A) and -resistant (17TUN-A) (panel B) accessions of Palmer amaranth (Amaranthus palmeri (S.) Wats.); greenhouse experiment, Shult Agricultural Research \& Extension Center, University of Arkansas, Fayetteville, AR, USA, in 2021.

The breakpoints at which each accession initiated stomatal closure were compared using their respective confidence intervals. The NTR response of Palmer amaranth to progressively drying soil followed the two-segmented linear regression, with $\mathrm{R}^{2}$ values ranging between 0.85 and 0.93 (Table 1 ).

Table 1. Breakpoint (threshold value for the initiation of stomatal closure), standard error (SE), $R^{2}$, and confidence intervals for the plateau regression analysis used to evaluate differences in drought tolerance between S-metolachlor-susceptible and -resistant Palmer amaranth (Amaranthus palmeri (S.) Wats.) accessions subjected to progressive drought; greenhouse experiment conducted at the Shult Agricultural Research \& Extension Center, University of Arkansas, Fayetteville, AR, USA, in 2021.

\begin{tabular}{cccccc}
\hline Accessions & Breakpoint $^{\mathbf{a}}$ & SE & $\mathbf{R}^{\mathbf{2}}$ & \multicolumn{2}{c}{ Confidence Intervals $^{\mathbf{b}}$} \\
\hline 09CRW-A & $0.17 \mathrm{a}$ & 0.007 & 0.85 & 0.15 & 0.19 \\
17TUN-A & $0.23 \mathrm{~b}$ & 0.004 & 0.93 & 0.22 & 0.25 \\
\hline
\end{tabular}

a Means within a column followed by different letters are significantly different $(p \leq 0.05) ;{ }^{\mathrm{b}} 95 \%$ confidence intervals of breakpoints.

The FTSWcr of the two accessions differed $(p \leq 0.05)$ (Table 1$)$, but no differences existed between breakpoints for the same accessions across runs $(p>0.05)$; therefore, 
data were pooled across runs for each accession. The $S$-metolachlor-resistant accession 17TUN-A had a greater FTSWcr than the $S$-metolachlor-susceptible accession 09CRW-A, indicating that the $S$-metolachlor-resistant accession started reducing its transpiration at higher threshold levels of $0.23 \pm 0.004$, with an $\mathrm{R}^{2}$ value of 0.93 , compared to the susceptible plants. The $S$-metolachlor-susceptible accession 09CRW-A started reducing its transpiration at a lower FTSWcr of $0.17 \pm 0.007$, with an $R^{2}$ value of 0.85 .

\subsection{Threshold Values for Stomatal Closure of Glyphosate-Resistant and-Susceptible Plants}

The glyphosate-susceptible and -resistant plants were chosen from one accession, 16CRW-D, based on EPSPS copy number. It was determined previously that resistance to glyphosate in this population is due to increased production of the target protein, EPSPS. The field population consisted of resistant and susceptible plants; the genomic diversity among these plants would be minimal, except for the traits contributing to glyphosate resistance. The relative EPSPS gene copy number detected in 16CRW-D ranged between 3 and 226. A total of 12 plants with EPSPS copy numbers between 22 and 165 (considered resistant) and 12 plants with EPSPS copy numbers $<10$ (which were considered susceptible [25]) were used for each run. The FTSWcr between plants with increased EPSPS copy numbers and plants with low gene copy numbers did not differ $(p>0.05)$. The NTR response of Palmer amaranth to progressively drying soil followed the two-segmented linear regression, with $\mathrm{R}^{2}$ values ranging between 0.90 and 0.91 (Table 2). The presence of more EPSPS copies in accession 16CRW-D did not change the breakpoint $(p>0.05)$ (Figure 3; Table 2). In other words, increasing the production of this key enzyme in the shikimate pathway had no effect on the initiation of stomatal closure under drought.

Table 2. Breakpoint (threshold value for the initiation of stomatal closure), standard error (SE), $R^{2}$, and confidence intervals for the plateau regression analysis used to evaluate differences in drought tolerance between glyphosate-susceptible and -resistant Palmer amaranth (Amaranthus palmeri (S.) Wats.) differing in EPSPS gene copy numbers; greenhouse experiment conducted at the Shult Agricultural Research \& Extension Center, University of Arkansas, Fayetteville, AR, USA, in 2021.

\begin{tabular}{lccccc}
\hline Genotype & Breakpoint $^{\mathbf{a}}$ & $\mathbf{S E}$ & $\mathbf{R}^{\mathbf{2}}$ & \multicolumn{2}{c}{ Confidence Intervals $^{\mathbf{b}}$} \\
\hline Glyphosate-resistant & $0.25 \mathrm{a}$ & 0.007 & 0.90 & 0.23 & 0.26 \\
Glyphoste-susceptible & $0.25 \mathrm{a}$ & 0.008 & 0.91 & 0.23 & 0.25 \\
\hline
\end{tabular}

${ }^{\text {a }}$ Means within a column followed by the same letter are not significantly different $(p>0.05) ;{ }^{b} 95 \%$ confidence intervals of breakpoints.

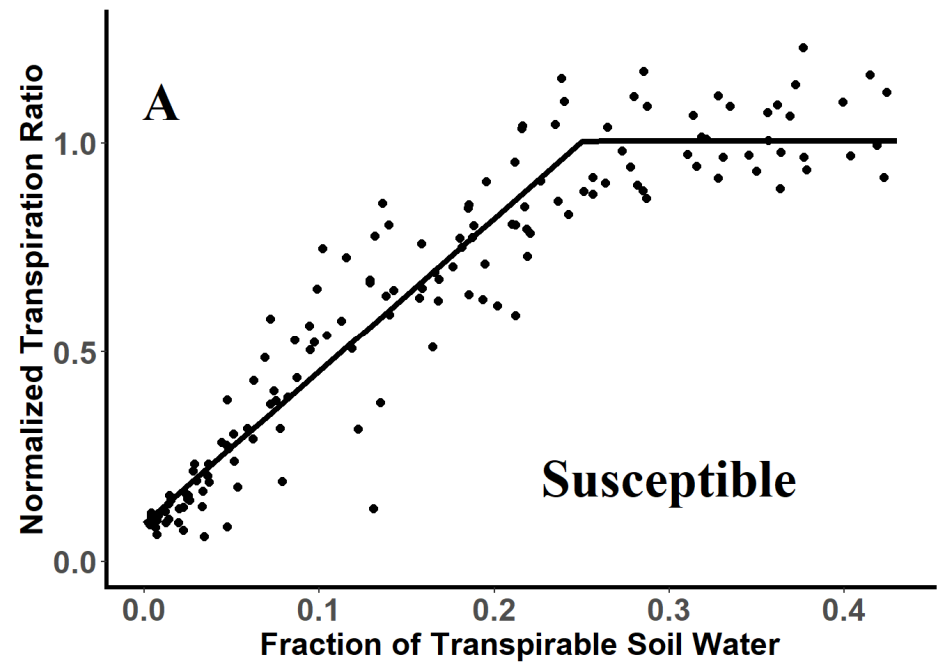

Figure 3. Cont. 


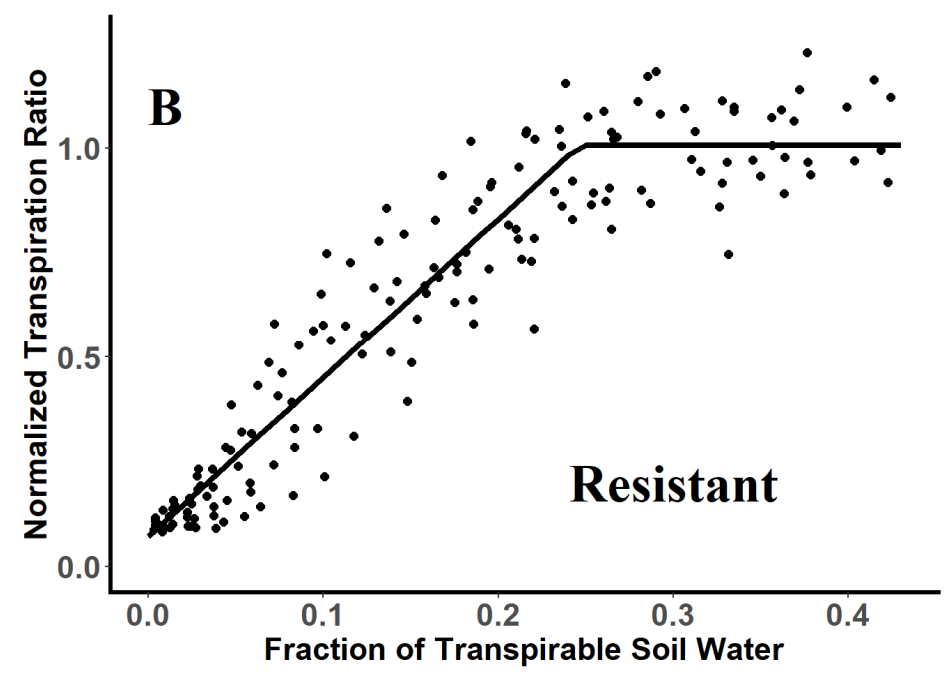

Figure 3. Relationship between normalized transpiration ratio (NTR) and fraction of transpirable soil water (FTSW) during soil drying cycle for glyphosate-susceptible (panel A) and -resistant (panel B) Palmer amaranth (Amaranthus palmeri (S.) Wats.) accessions differing by their EPSPS gene copy number; greenhouse experiment conducted at the Shult Agricultural Research \& Extension Center, University of Arkansas, Fayetteville, AR, USA, in 2021. (A) plants with EPSPS copy numbers < 10; (B) EPSPS copy numbers between 22 and 165.

\section{Discussion}

\subsection{Differential Response of S-Metolachlor-Resistant and-Suceptible Accessions to} Daily Transpiration

The advantages of early and late breakpoints are interpreted diversely by authors, and depend on drought scenarios [34,35]. With the smaller FTSWcr in this study, the $S$-metolachlor-susceptible accession was likely to sustain its normal transpiration and prevent growth reduction during short-term water stress [34]. On the other hand, the $S$-metolachlor-resistant accession with greater FTSWcr has an advantage under long-term water stress and drier conditions [31]. Greater FTSWcr means early stomatal closure with respect to the initiation of water deficit. By doing this, the plant conserves water and delays desiccation or mitigates drought stress, thereby enhancing the plant's survival under prolonged drought $[13,14,17,36]$. In nature, this would increase the probability of survival until the next rain event.

$S$-metolachlor resistance reported in Arkansas is attributed to an increase in metabolism of the herbicide in the plants catalyzed by glutathione $S$-transferases (GSTs) [26]. As multifunctional enzymes encoded by large gene families, GSTs are known to play a protective role against different biotic and abiotic stresses, including xenobiotics and oxidative stress [24,37]. Overexpression of GST genes might have improved drought tolerance in the resistant accession. GSTs have been used to confer drought tolerance to transgenic tobacco [38-40] and transgenic Arabidopsis plants [41,42]. Data from previous and current experiments on $S$-metolachlor-resistant Palmer amaranth collectively indicate that the GST-mediated resistance mechanism could increase tolerance to drought in resistant plants. We observed this expected latent effect in the present study; however, we could not attribute increased drought tolerance solely to the $S$-metolachlor NTSR mechanism, because the reference susceptible plants did not come from the same population as the resistant plants. The baseline tolerance to drought could be different between resistant and susceptible populations coming from different localities. Moreover, the resistance profile of the 17TUN-A has not yet been fully characterized. If this population also happens to be resistant to other herbicide modes of action, there may be different NTSR mechanisms associated with other herbicide modes of action that could also contribute to drought tolerance in this population. Regardless of the possible involvement of other resistance mechanisms that could also confer increased tolerance to drought, the practical lesson is 
that $S$-metolachlor-resistant populations may become even more competitive with crops than the susceptible populations.

\subsection{No Difference in Threshold Values for Stomatal Closure between Glyphosate-Resistant and -Susceptible Plants}

It has been hypothesized that the amplification of EPSPS gene copy numbers could divert a significant fraction of fixed carbon resources away from the normal metabolic processes towards producing more of the EPSPS protein. If so, then this mechanism of resistance could have negative physiological consequences that could reduce plants' fitness. However, researchers have reported no effect of EPSPS gene amplification on the fitness of glyphosate-resistant kochia [43] and Palmer amaranth [44,45]. It could be argued that fitness costs might not have been detected in these past studies because the plants were not exposed to certain stress factor(s), with or without competition. In the present study, Palmer amaranth with high EPSPS copy numbers also did not show fitness penalties when subjected to progressive drying. In this case, fitness was assessed in terms of the ability to mitigate desiccation from water deficit by curbing transpiration sooner after the onset of drought stress. Glyphosate-resistant and -susceptible plants from the same field populations exhibited the same response to drought stress. Being the key enzyme in the shikimate synthesis pathway, EPSPS does not play a role in drought stress mitigation.

Fitness penalties may also manifest in terms of reduced fecundity, seed germination capacity, seedling vigor, competitive ability, or even the ability to recover from stress. It is interesting to note that the NTSR mechanism involving reduced absorption and translocation of glyphosate in rigid ryegrass (Lolium rigidum Gaud.) resulted in reduced fitness with or without competition with wheat $[46,47]$. The fitness cost manifested in terms of reduced seed production of resistant plants compared to susceptible ones, both with low-density wheat competition and without wheat competition. In this case, the evolved resistance mechanism came with a fitness penalty, unlike the EPSPS gene amplification resistance mechanism and the GST-associated resistance mechanism discussed previously. Several aspects of plant physiology and growth need to be investigated in order to fully understand the effect of herbicide resistance mechanisms on weediness and fitness.

\section{Conclusions}

The GST-mediated resistance to $S$-metolachlor may impart some tolerance to drought stress. This is a logical consequence of the diverse roles played by GSTs in general stress mitigation and intrinsic plant protection. This can be verified by developing near-isolines of resistant and susceptible plants and conducting stress experiments on these materials. In contrast, EPSPS gene amplification does not affect the response of Palmer amaranth to drought stress with respect to reducing water loss. As droughts are predicted to increase in frequency and severity, these results suggest that $S$-metolachlor-resistant and glyphosate-resistant Palmer amaranth populations will not be at a competitive disadvantage compared to susceptible genotypes. Instead, the $S$-metolachlor-resistant populations may even be more competitive than the susceptible ones. Alternative and diverse management strategies will be required for effective Palmer amaranth control regardless of herbicide resistance status.

Author Contributions: Conceptualization, N.R.-B. and K.B.-J.K.; data curation, K.B.-J.K. and N.R.-B.; formal analysis, K.B.-J.K.; funding acquisition, N.R.-B. and T.R.B.; investigation, K.B.-J.K. and G.R.; methodology, K.B.-J.K. and N.R.-B.; project administration, M.C.S. and N.R.-B.; resources, N.R.-B.; supervision, N.R.-B.; validation, K.B.-J.K., G.R. and N.R.-B.; visualization, K.B.-J.K.; writing-original draft preparation, K.B.-J.K.; writing—review and editing, N.R.-B., M.C.S., T.R.B., K.B.-J.K. and M.B.B. All authors have read and agreed to the published version of the manuscript.

Funding: Financial support for this research was provided by Arkansas soybean producers through check-off funds administered by the Arkansas Soybean Promotion Board and the USDA National Institute of Food and Agriculture, Hatch 1011804. 


\section{Institutional Review Board Statement: Not applicable.}

Informed Consent Statement: Not applicable.

Acknowledgments: The authors thank the University of Arkansas' System Division of Agriculture for all other personnel support and facilities. The authors also thank Pâmela Carvalho-Moore and Fidel Gonzalez-Torralva for their assistance in laboratory-related work.

Conflicts of Interest: The authors declare no conflict of interest.

\section{References}

1. Khan, A.; Pan, X.D.; Najeeb, U.; Tan, D.K.Y.; Fahad, S.; Zahoor, R.; Luo, H.H. Coping with drought: Stress and adaptive mechanisms, and management through cultural and molecular alternatives in cotton as vital constituents for plant stress resilience and fitness. Biol. Res. 2018, 51, 47. [CrossRef] [PubMed]

2. Boyer, J.S.; Byrne, P.; Cassman, K.G.; Cooper, M.; Delmer, D.; Greene, T.; Gruis, F.; Habben, J.; Hausmann, N.; Kenny, N.; et al. The US drought of 2012 in perspective: A call to action. Glob. Food Secur.-Agric. Policy Econ. Environ. 2013, 2, 139-143. [CrossRef]

3. Jin, C.; Luo, X.; Xiao, X.M.; Dong, J.W.; Li, X.M.; Yang, J.; Zhao, D.Y. The 2012 Flash Drought Threatened US Midwest Agroecosystems. Chin. Geogr. Sci. 2019, 29, 768-783. [CrossRef]

4. Liu, L.; Basso, B. Impacts of climate variability and adaptation strategies on crop yields and soil organic carbon in the US Midwest. PLoS ONE 2020, 15, e0225433. [CrossRef] [PubMed]

5. Lobell, D.B.; Deines, J.M.; Di Tommaso, S. Changes in the drought sensitivity of US maize yields. Nat. Food 2020, 1, 729-735. [CrossRef]

6. Bowling, L.C.; Cherkauer, K.A.; Lee, C.I.; Beckerman, J.L.; Brouder, S.; Buzan, J.R.; Doering, O.C.; Dukes, J.S.; Ebner, P.D.; Frankenberger, J.R.; et al. Agricultural impacts of climate change in Indiana and potential adaptations. Clim. Chang. 2020, 163, 2005-2027. [CrossRef]

7. Kropff, M.; van Laar, H. Modelling Crop-Weeds Interactions; CAB International: Wallingford, UK, 1993.

8. Kimm, H.; Guan, K.Y.; Gentine, P.; Wu, J.; Bernacchi, C.J.; Sulman, B.N.; Griffis, T.J.; Lin, C.J. Redefining droughts for the US Corn Belt: The dominant role of atmospheric vapor pressure deficit over soil moisture in regulating stomatal behavior of Maize and Soybean. Agric. For. Meteorol. 2020, 287, 107930. [CrossRef]

9. Grassini, P.; Torrion, J.A.; Yang, H.S.; Rees, J.; Andersen, D.; Cassman, K.G.; Specht, J.E. Soybean yield gaps and water productivity in the western US Corn Belt. Field Crops Res. 2015, 179, 150-163. [CrossRef]

10. Yang, Y.; Anderson, M.C.; Gao, F.; Johnson, D.M.; Sun, L.; Dulaney, W.; Hain, C.R.; Otkin, J.A.; Prueger, J.; Meyers, T.P.; et al. Phenological corrections to a field-scale, ET-based crop stress indicator: An application to yield forecasting across the US Corn Belt. Remote Sens. Environ. 2021, 257, 112337. [CrossRef]

11. Li, L.J.; Song, X.Y.; Xia, L.; Fu, N.; Feng, D.; Li, H.Y.; Li, Y.L. Modelling the effects of climate change on transpiration and evaporation in natural and constructed grasslands in the semi-arid Loess Plateau, China. Agric. Ecosyst. Environ. 2020, 302, 107077. [CrossRef]

12. Saradadevi, R.; Palta, J.A.; Siddique, K.H.M. ABA-mediated stomatal response in regulating water use during the development of terminal drought in wheat. Front. Plant Sci. 2017, 8, 743-764. [CrossRef] [PubMed]

13. Sinclair, T.R. Is transpiration efficiency a viable plant trait in breeding for crop improvement? Funct. Plant Biol. 2012, 39, 359-365. [CrossRef] [PubMed]

14. Cathey, S.E.; Kruse, J.K.; Sinclair, T.R.; Dukes, M.D. Transpiration and visual appearance of warm season turfgrasses during soil drying. Environ. Exp. Bot. 2013, 89, 36-43. [CrossRef]

15. Sinclair, T.; Ludlow, M. Influence of soil-water supply on the plant water-balance of 4 tropical grain legumes. Aust. J. Plant Physiol. 1986, 13, 329-341. [CrossRef]

16. Ray, J.; Gesch, R.; Sinclair, T.; Allen, L. The effect of vapor pressure deficit on maize transpiration response to a drying soil. Plant Soil 2002, 239, 113-121. [CrossRef]

17. Ray, J.; Sinclair, T. Stomatal closure of maize hybrids in response to drying soil. Crop Sci. 1997, 37, 803-807. [CrossRef]

18. Ray, J.; Samson, B.; Sinclair, T. Vegetative growth and soil water extraction of two maize hybrids during water deficits. Field Crops Res. 1997, 52, 135-142. [CrossRef]

19. Ray, J.; Sinclair, T. The effect of pot size on growth and transpiration of maize and soybean during water deficit stress. J. Exp. Bot. 1998, 49, 1381-1386. [CrossRef]

20. Bravo, W.; Leon, R.; Ferrell, J.; Mulvaney, M.; Wood, C. Evolutionary adaptations of Palmer amaranth (Amaranthus palmeri) to nitrogen fertilization and crop rotation history affect morphology and nutrient-use efficiency. Weed Sci. 2018, 66, 180-189. [CrossRef]

21. Ehleringer, J. Ecophysiology of Amaranthus palmeri: A Sonoran desert summer annual. Oecologia 1983, 57, 107-112. [CrossRef]

22. Butts, T.R.; Vieira, B.C.; Latorre, D.O.; Werle, R.; Kruger, G.R. Competitiveness of herbicide-resistant waterhemp (Amaranthus tuberculatus) with soybean. Weed Sci. 2018, 66, 729-737. [CrossRef]

23. Tardif, F.J.; Rajcan, I.; Costea, M. A mutation in the herbicide target site acetohydroxyacid synthase produces morphological and structural alterations and reduces fitness in Amaranthus powellii. New Phytol. 2006, 169, 251-264. [CrossRef] [PubMed] 
24. Montellano, P. Cytochrome P450: Structure, Mechanism, and Biochemistry, 3rd ed.; Plenum Publishers: New York, NY, USA, 2005.

25. Singh, S.; Singh, V.; Lawton-Rauh, A.; Bagavathiannan, M.; Roma-Burgos, N. EPSPS gene amplification primarily confers glyphosate resistance among Arkansas Palmer amaranth (Amaranthus palmeri) populations. Weed Sci. 2018, 66, 293-300. [CrossRef]

26. Rangani, G.; Noguera, M.; Salas-Perez, R.; Benedetti, L.; Roma-Burgos, N. Mechanism of resistance to S-metolachlor in Palmer amaranth. Front. Plant Sci. 2021, 12, 13. [CrossRef]

27. King, C.; Purcell, L. Evaluation of methods for estimating transpiration response to soil drying for container-grown plants. Crop Sci. 2017, 57, 2143-2148. [CrossRef]

28. Schmidt, J.; Blankenship, E.; Lindquist, J. Corn and velvetleaf (Abutilon theophrasti) transpiration in response to drying soil. Weed Sci. 2011, 59, 50-54. [CrossRef]

29. King, C.; Purcell, L.; Brye, K. Differential wilting among soybean genotypes in response to water deficit. Crop Sci. 2009, 49, 290-298. [CrossRef]

30. R Core Team. R: A Language and Environment for Statistical Computing, 3.5.1; R Foundation for Statistical Computin: Vienna, Austria, 2018.

31. Sinclair, T.R.; Manandhar, A.; Belko, N.; Riar, M.; Vadez, V.; Roberts, P.A. Variation among cowpea genotypes in sensitivity of transpiration rate and symbiotic nitrogen fixation to soil drying. Crop Sci. 2015, 55, 2270-2275. [CrossRef]

32. Sinclair, T.R.; Shekoofa, A.; Isleib, T.G.; Balota, M.; Zhang, H. Identification of Virginia-type peanut genotypes for water-deficit conditions based on early decrease in transpiration rate with soil drying. Crop Sci. 2018, 58, 2607-2612. [CrossRef]

33. Devi, M.J.; Reddy, V. Cotton genotypic variability for transpiration decrease with progressive soil drying. Agronomy 2020, 10, 1290. [CrossRef]

34. Fuentealba, M.P.; Zhang, J.; Kenworthy, K.; Erickson, J.; Kruse, J.; Trenholm, L. Transpiration responses of warm-season turfgrass in relation to progressive soil drying. Sci. Hortic. 2016, 198, 249-253. [CrossRef]

35. Miller, G.L. Physiological response of bermudagrass grown in soil amendments during drought stress. Hortscience 2000, 35, 213-216. [CrossRef]

36. Devi, M.J.; Sinclair, T.R.; Vadez, V.; Krishnamurthy, L. Peanut genotypic variation in transpiration efficiency and decreased transpiration during progressive soil drying. Field Crops Res. 2009, 114, 280-285. [CrossRef]

37. Lee, J.; Jo, H.; Kong, K. A plant-specific tau class glutathione S-transferase from Oryza sativa having significant detoxification activity towards chloroacetanilide herbicides. Bull. Korean Chem. Soc. 2011, 32, 3756-3759. [CrossRef]

38. George, S.; Venkataraman, G.; Parida, A. A chloroplast-localized and auxin-induced glutathione S-transferase from phreatophyte Prosopis juliflora confer drought tolerance on tobacco. J. Plant Physiol. 2010, 167, 311-318. [CrossRef] [PubMed]

39. Ji, W.; Zhu, Y.M.; Li, Y.; Yang, L.A.; Zhao, X.W.; Cai, H.; Bai, X. Over-expression of a glutathione S-transferase gene, GsGST, from wild soybean (Glycine soja) enhances drought and salt tolerance in transgenic tobacco. Biotechnol. Lett. 2010, 32, 1173-1179. [CrossRef] [PubMed]

40. Liu, D.; Liu, Y.; Rao, J.; Wang, G.; Li, H.; Ge, F.; Chen, C. Overexpression of the glutathione S-transferase gene from Pyrus pyrifolia fruit improves tolerance to abiotic stress in transgenic tobacco plants. Mol. Biol. 2013, 47, 515-523. [CrossRef]

41. Xu, J.; Zheng, A.Q.; Xing, X.J.; Chen, L.; Fu, X.Y.; Peng, R.H.; Tian, Y.S.; Yao, Q.H. Transgenic Arabidopsis plants expressing grape glutathione $S$-transferase gene (VvGSTF13) show enhanced tolerance to abiotic stress. Biochemistry 2018, 83, 755-765. [CrossRef]

42. Yang, Q.; Liu, Y.J.; Zeng, Q.Y. Overexpression of three orthologous glutathione S-transferases from Populus increased salt and drought resistance in Arabidopsis. Biochem. Syst. Ecol. 2019, 83, 57-61. [CrossRef]

43. Osipitan, O.A.; Dille, J.A. No Impact of Increased EPSPS Gene Copy Number on Growth and Fecundity of Glyphosate-Resistant Kochia (Bassia scoparia). Weed Sci. 2019, 67, 22-28. [CrossRef]

44. Giacomini, D.; Westra, P.; Ward, S.M. Impact of genetic background in fitness cost studies: An example from glyphosate-resistant Palmer amaranth. Weed Sci. 2014, 62, 29-37. [CrossRef]

45. Vila-Aiub, M.; Goh, S.; Gaines, T.; Han, H.; Busi, R.; Yu, Q.; Powles, S. No fitness cost of glyphosate resistance endowed by massive EPSPS gene amplification in Amaranthus palmeri. Planta 2014, 239, 793-801. [CrossRef] [PubMed]

46. Lorraine-Colwill, D.F.; Powles, S.B.; Hawkes, T.R.; Hollinshead, P.H.; Warner, S.A.J.; Preston, C. Investigations into the mechanism of glyphosate resistance in Lolium rigidum. Pestic. Biochem. Physiol. 2002, 74, 62-72. [CrossRef]

47. Pedersen, B.; Neve, P.; Andreasen, C.; Powles, S. Ecological fitness of a glyphosate-resistant Lolium rigidum population: Growth and seed production along a competition gradient. Basic Appl. Ecol. 2007, 8, 258-268. [CrossRef] 